\title{
Changing professional service archetypes in a law firm using Process Orientated Holonic (PrOH) Modelling
}

Ben Clegg ${ }^{a}$, Krishna Balthu ${ }^{a}$, Glyn Morris ${ }^{b}$

aperations and Information Management Department, Aston Business School, Aston University, Birmingham, UK.

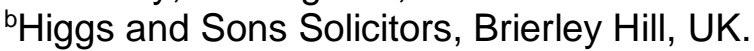

To cite this article: Ben Clegg, Krishna Balthu \& Glyn Morris (2019): Changing professional service archetypes in a law firm using Process Orientated Holonic ( $\mathrm{PrOH}$ ) Modelling, Knowledge Management Research \& Practice, DOI: 10.1080/14778238.2019.1571387

To link to this article: https://doi.org/10.1080/14778238.2019.1571387

Published online: 04 Feb 2019

\section{Abstract}

This paper gives an in depth action research case study on how organisational change has been implemented in a medium-sized law firm in the UK (Higgs \& Sons). The Canonical Action Research process was followed and a specific novel type of Soft Systems Methodology (SSM) known as Process Oriented Holonic (PrOH) Modelling was used to define systemic problems, support knowledge-based decision-making and implement change. This study found that as a result of increased competition, Higgs \& Sons successfully transformed some of its services from a 'professional partnership $\left(P^{2}\right)$ ' delivery style towards having greater 'managed professional business' (MPB) characteristics, but found that not all of its services were suited to this change, and that different types of service styles were necessary on a service by service basis. Practical changes and implications are discussed in the context of Pinnington and Morris' (2003) 'professional partnership' $\left(P^{2}\right)$ and 'managed professional business' (MPB) archetype template.

Keywords: professional services, soft systems methodology, action research, knowledge management, innovation, small-to-medium sized enterprise (SME)

Type: original article

Acknowledgments: This research was part-funded by InnovateUK and the ERDF.

Ben Clegg, Krishna Balthu \& Glyn Morris (2019): Changing professional service archetypes in a law firm using Process Orientated Holonic (PrOH) Modelling, Knowledge Management Research \& Practice, DOI: 


\section{Introduction: changing law practice}

Law firms have traditionally been conservative in their approach to client-centred service, slow to adapt to changing market needs and often detached from modern operational and knowledge management practices (Falconer, 2005); even though they are also knowledge intensive business (KIBS) (Bolsani, 2016). Pressure to change is mounting as clients seek increased value for money and new competitors, such as supermarkets and insurance companies, enter the legal space by taking advantage of new Alternative Business Structure (ABS) (The Guardian, 2012; SLA, 2016).

Incumbent law firms risk losing business as increased competition and lower prices from new entrants prove to be more proficient at delivering mass services; and are able to entice their customers away from the hallowed grounds of traditional professional law firms towards mass legal services through lower prices and no-hassle standardised services (as per Schmenner, 1986). As a consequence professionalism, productivity and efficiency debates have taken centre stage in the delivery of legal services; and operations management practices and values from the manufacturing and production sector have begun to imbue themselves into the delivery of professional services (SRA, 2016); which for many in the legal profession irks at the soul of professionalism and jars at the ethos of professional service provision (Freidson, 2001), especially in the relatively conservatively-minded legal sector.

Research indicates that law firms are generally moving towards the managed professional business (MPB) archetype and away from the professional partnership $\left(P^{2}\right)$ form of governance and operations management (Segal-Horn and Dean, 2007); but in spite of this overall trend, research also indicates that partners of law firms remain at the centre of power when it comes to making strategic decisions and controlling client relations (Pinnington \& Morris, 2003). With these issues in mind we use Higgs \& Sons, a long-established small-to-medium sized law enterprise (SME) in the UK, to demonstrate innovation in the deregulated legal sector (after the 2007 Legal Services Act; HMSO, 2007). This is in respect to: identifying endogenous and 
exogenous forces influencing practices, and designing and applying suitable interventions to achieve change.

An action research team conducted this project over a two year period; it consisted of academics from a university and lawyers and professional support staff from Higgs \& Sons. The aims of this project were to use action research to:

(i) better understand strategic, knowledge and operations management innovation opportunities (Van de Ven, 2007) within a professional service,

(ii) implement changes, where necessary, to become a more appropriate blend of professional service delivery styles relative to legal services being provided. (iii) use relevant theory via abductive logic.

Similar studies in KIBS SMEs (e.g. accountancy, and architectural firms) have called for techniques that allow emergent behaviours to be surfaced (e.g. Bolisani et al., 2016). In this study a specific type of Soft Systems Methodology (SSM) known as Process Oriented Holonic $(\mathrm{PrOH})$ Modelling was used to facilitate these transformations as it allows for emergent (and hidden) properties of strategic thinking, knowledge-based decision-making and operations management practice to be surfaced.

\section{Reference Frameworks for Professional Services}

Professional Service Firms (PSFs) have attracted much interest from management researchers (Pilkington and Chai, 2008) and are often used as examples of good service operations management practice for an economy which is becoming increasingly knowledge-based (Empson, 2007). For example Morris and Empson, (1998) describe how focusing on knowledge-based decision making can affect most aspects of an organization including structure, systems, routines and beliefs, professionalism, finances and marketability. Other studies focus on high-level knowledge-based decisions and institutional change (e.g. Nelson, 1988, Galanter and Palay, 1991; Cooper, et al., 1996; Sherer and Lee, 2002; Pinnington and Morris, 
2003), while other studies look at detailed knowledge tactics and operational changes (e.g. Smets et al., 2012), and strategic, knowledge and operations management issues in professional service firms (e.g. Prajogo and McDermott, 2008).

Operations management theory treats professional services as one of the purest forms of service (Schmenner, 1986; Goodale, et al., 2008); and studies reveal that theory development and application in action research is still generally underdeveloped (Kaiser and Ringlstetter, 2011; Machuca, et al., 2007). For instance: some studies have focused on clarifying what is and what isn't a PSF based on service intensity and managerial implications (Nordenflycht, 2010); while others (e.g. Lewis and Brown, 2012) have refined theory, stating that PSFs are services which involve high levels of knowledge intensity, labour intensity, customer interaction and customisation (e.g. Schmenner, 1986; Silvestro et al., 1992).

Via abductive rationalisation (Lawson, 1998) Pinnington \& Morris's template of archetypes (2003) (seen in Table 1) was found to be the most relevant frame of reference for this research; it was used as the primary framework to describe changes in Higgs \& Sons. For this study and other related research, 'An archetype is defined here in terms of two general statements. First, organizational structures and management systems are best understood by analysis of overall patterns rather than by analysis of narrowly drawn sets of organizational properties. This is the "holistc" perspective asserted by Miller and Friesen (1984). Second patterns are a function of the ideas, beliefs, and values - the components of an "interpretive scheme" (Ranson, Hinings \& Greenwood, 1980) - that underpin and are embodied in organizational structures and systems. An archetype is thus a set of structures and systems that reflects a single interpretive scheme' (Greenwood and Hinings (1993).

Pinnington and Morrris (2003) state that, although no single organisation may conform exactly to their template, elements of it should be "empirically observable", this was the case with Higgs \& Sons as these elements were observable to varying degrees in specific legal services. The MPB archetype is based upon Cooper et als. (1996) research and the $\mathrm{P}^{2}$ archetype is based upon Greenwood et als. (1990) research.

Ben Clegg, Krishna Balthu \& Glyn Morris (2019): Changing professional service archetypes in a law firm using Process Orientated Holonic (PrOH) Modelling, Knowledge Management Research \& Practice, DOI: 


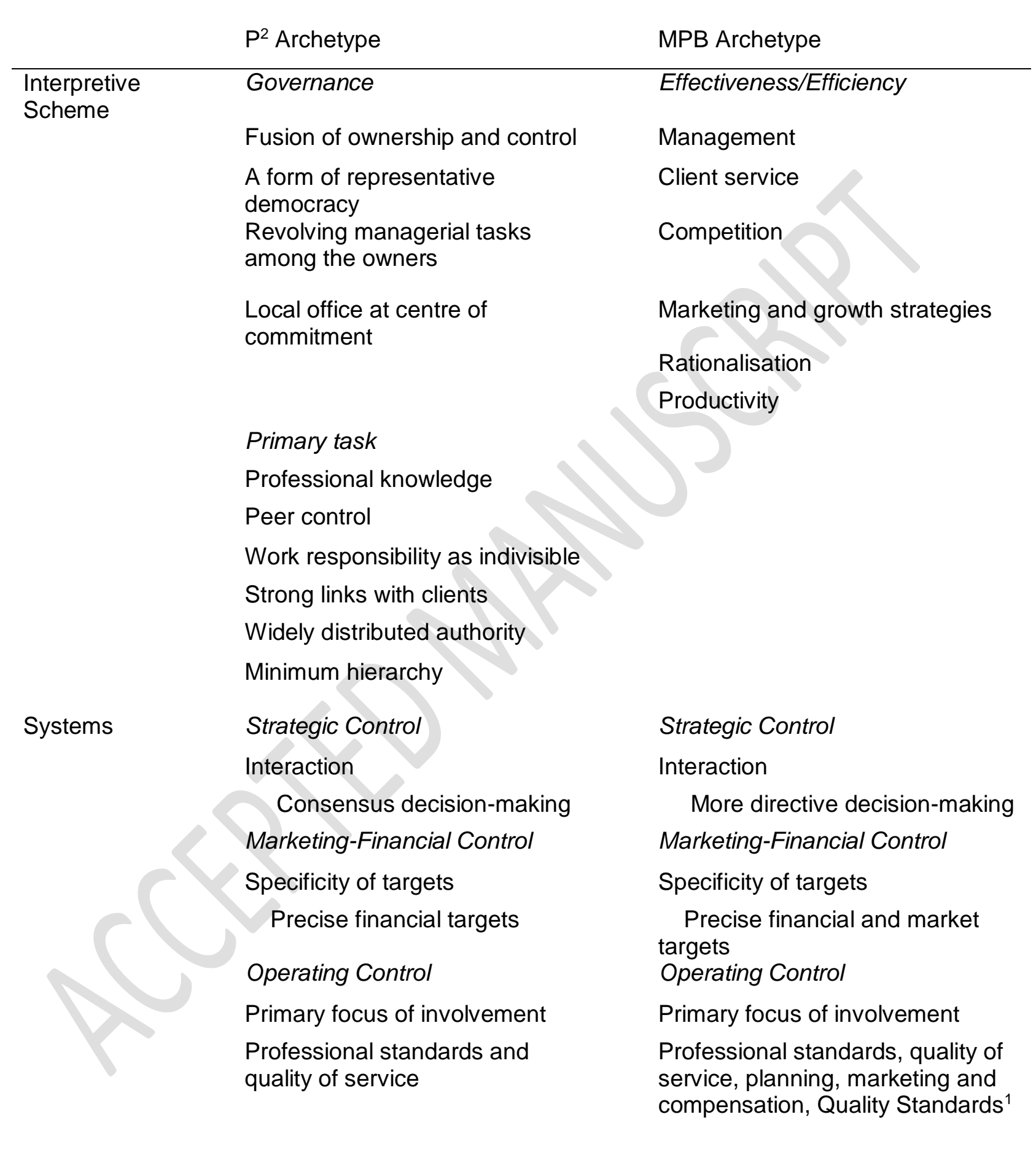

Table 1: Professional Partnerships $\left(\mathrm{P}^{2}\right)$ and Managed Professional Business (MPB) Archetypes. Source: Pinnington and Morris (2003)

Ben Clegg, Krishna Balthu \& Glyn Morris (2019): Changing professional service archetypes in a law firm using Process Orientated Holonic (PrOH) Modelling, Knowledge Management Research \& Practice, DOI: 
Building on Pinnington and Morris' archetype template, Smets et al. (2012) argue that micro-level factors, involving everyday work of individuals can influence change at the institution-level and believes that tactical factors are also important to consider; but are often largely neglected in PSF studies. In response to these shortfalls this study describes both tactical and strategic level changes in the context of Pinnington and Morris' archetype template using Higgs \& Sons as an empirical illustration.

\section{Case Study: Higgs \& Sons}

Higgs and Sons is a long-established legal practice, trading for over 140 years. The firm delivers a wide range of legal services to clients of all sizes - individuals, SMEs and large Public Limited Companies (PLC's). This paper describes how this mediumsized firm grew from 16 equity partners, 150 staff and a revenue of $£ 11.2 \mathrm{~m}$ in 2011 to have 18 partners, 217 staff and revenue of $£ 15.6 m$ for its year ending 2015 . Higgs \& Sons is a legal partnership comprising of equity partners, salaried partners and junior lawyers (associates and solicitors). Lawyers work alongside non-lawyers undergoing on-the-job training, non-lawyers provide business and administration support, paralegal and secretarial services.

In many ways in 2011 Higgs and Sons, with its total of nine different legal services and diversified client base, ranging from 'off-the-street' clients to large PLCs, gave an exemplary case of the $\mathrm{P}^{2}$ archetype (see Table 1 ) and was ideally positioned to answer key questions on knowledge-and-operations-based transitions towards an MPB structure (see Table 1). This was possible because from the onset of this action research project, Higgs \& Sons was an organisation intent on making strategic changes away from a traditional professional partnership $\left(\mathrm{P}^{2}\right)$ towards being more innovative and adaptable to external changes asymptotic to the MPB archetype.

Despite Higgs \& Sons initial strategic intent, the prevailing initial internal prevailing culture and structure in Higgs \& Sons was overwhelmingly traditional $\left(\mathrm{P}^{2}\right)$ and resistant to change; and so this project was launched to remove some inertia and catalyse innovation.

Ben Clegg, Krishna Balthu \& Glyn Morris (2019): Changing professional service archetypes in a law firm using Process Orientated Holonic (PrOH) Modelling, Knowledge Management Research \& Practice, DOI: 
Similar topic cases are reported by Lawrence et al. (2012) focusing on the role of power types in archetype change in professional service firms, by Jonsson, (2015) focusing on knowledge management and change, and by Hinings et al (1991) focusing on organizational 'modules' in an accountancy firm (which are equivalent to different 'services' in this study).

\section{Canonical Action Research Process}

Canonical Action Research (CAR) (Susman and Evered, 1978) was used as this study's process of research. An abductive action research stance (Spens and Kovacs, 2006) was also taken (rather than inductive or deductive) as it supports "reasoning from effect to causes or explanations" (Lamma et al., 1999). In its radical form abductive logic tries to explain a "puzzling observation or an anomaly that cannot be explained using established theory" (Andreewsky and Bourcier, 2000; Dubois and Gadde, 2002). A milder application of abductive logic is used in this study to explain the unnecessarily sedimented changes in respect to the delivery of legal services in a mid-sized law company in the UK). Abductive logic also uses a "deliberate application of an alternative theory for explaining a phenomenon" (Kirkeby, 1990). For instance In this case study. Pinnington and Morris's archetype template provides one explanation, among many possible alternative explanations for observations via "theory matching" (Spens and Kovacs, 2006) to illuminate further theorizing about the initial puzzle, observation or system under observation and/or to catalyse interventions. This approach encourages open interpretation of complex systemic issues without imposing preconceived concepts. In further support of this approach Checkland states that, "there must be an intellectual framework, declared ... in which general learning outcomes can be defined. Without such a framework, action research can quickly become indistinguishable from mere action" (Checkland, 1981, p.400). Calls for more innovative approaches to explore service encounters, such as this, can be found in the literature (e.g. Svensson, 2006).

Ben Clegg, Krishna Balthu \& Glyn Morris (2019): Changing professional service archetypes in a law firm using Process Orientated Holonic (PrOH) Modelling, Knowledge Management Research \& Practice, DOI: 
By using the CAR approach, and abductive logic, specific elements (Checkland and Scholes, 1996) of legal services were realigned to Higgs \& Sons' strategic objectives; other systems thinking approaches, as critiqued by Jackson (2005), could also have been used in such a scenario.

\subsection{Research Process}

Susman and Evered's (1978) five stage CAR process is shown in Figure 1; its five stages are: defining the issue, planning action/intervention, taking action/intervening, analysing and reflecting on action, and engaging with real world setting/situation. Each stage's actions and findings are reported below in keeping with the nature of action research.

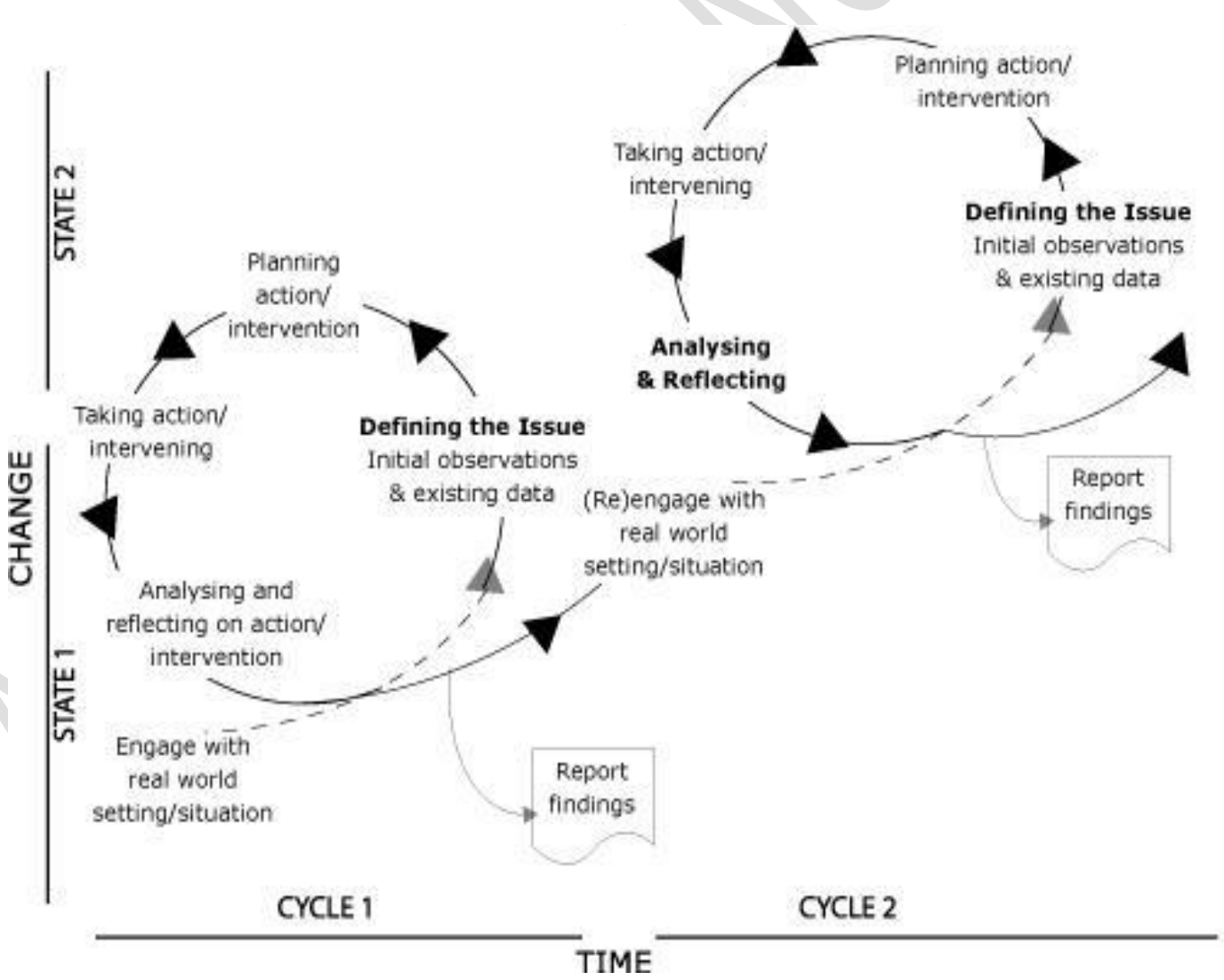

Figure 1: Canonical Action Research (CAR) process used (Susman and Evered, 1978) 
Roles were assigned to people in the action research team: to those in situ (in Higgs \& Sons) who acted as data collectors, and to the academic team members who acted as 'facilitators' and 'activists' (Voss, 2009; Voss et al., 2016) who conducted enquiries into situational conditions to help transform practices (from $\mathrm{P}^{2}$ towards MPB).

\subsubsection{CAR Stage 1 - Defining the Issue}

Hayes and Wheelwright's (1979a, 1979b) volume and variety contingency framework along with Silvestro' et al's' (1992) adaptions for services was used as an a priori framework to define and select contrasting services to use in this study. Five legal services were chosen, as identified and characterised in Table 2, from nine at Higgs \& Sons, these were chosen to represent a cross section of services by volume and variety (Hayes and Wheelwright, 1979a, 1979b) because it is widely accepted that processes with different output volumes and varieties require different designs, controls, technological support, measures of efficiency and effectiveness, and levels of knowledge-based intensity, professionalism (Silvestro et al., 1992) and 'managerialism' (Pinnington and Morris, 2003). These five services are further characterised in Silvestro's et al.'s (1992) Volume-Variety Matrix for services (see Figure 2); they are: Road Traffic Accident (RTA) Claims; Wills and Estate Administrations (Wills); Commercial Property; Dispute Resolution; and Corporate Services. Stage 1 took approximately one month.

\begin{tabular}{|l|l|l|}
\hline Legal Service & Volume & Variety \\
\hline Road Traffic Accident Claims (RTA) & High & Low \\
\hline Wills and Estate Administration (Wills) & High & Low \\
\hline Commercial Property & High & High \\
\hline Dispute Resolution & Low & High \\
\hline Corporate Services & Low & High \\
\hline
\end{tabular}

Table 2: Volume-Variety characterisation for five service Departments at Higgs \& Sons

Ben Clegg, Krishna Balthu \& Glyn Morris (2019): Changing professional service archetypes in a law firm using Process Orientated Holonic (PrOH) Modelling, Knowledge Management Research \& Practice, DOI: 


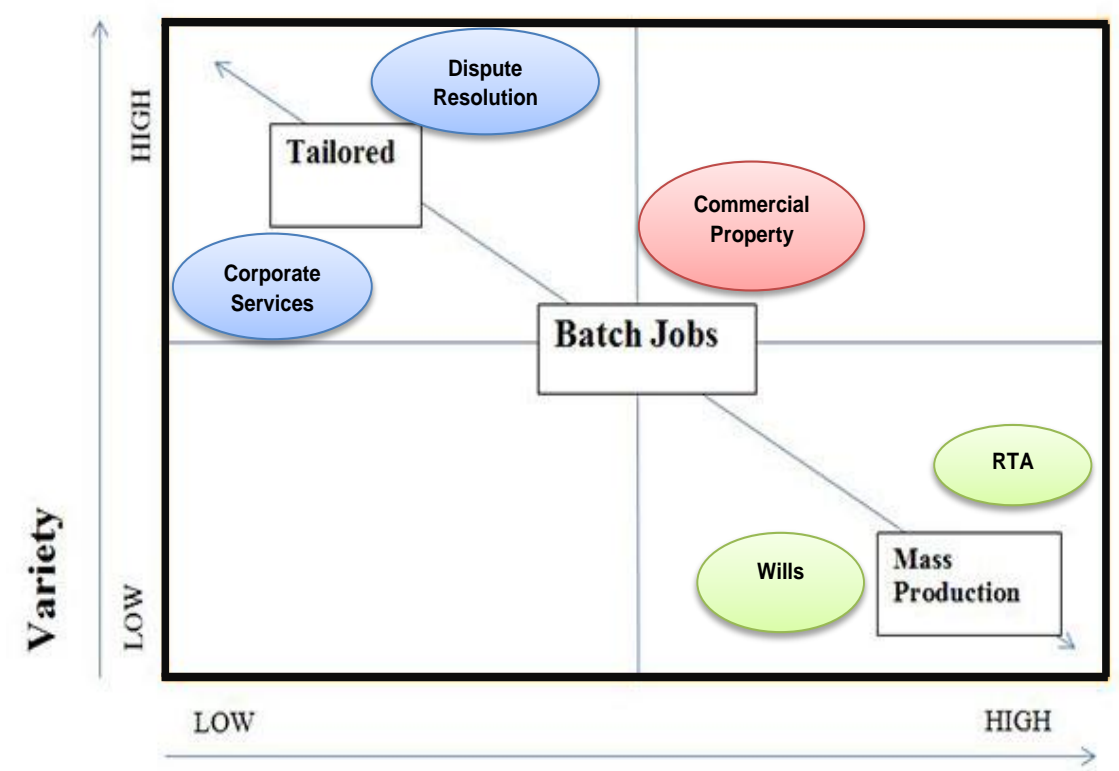

Volume

Figure 2: Volume-Variety matrix adapted from Silvestro et al. (1992).

\subsubsection{CAR Stage 2 - Planning Action / Intervention}

Process Orientated Holonic (PrOH) Modelling (Clegg, 2007) was used to model each legal service and the overall company strategy. PrOH modelling, like all SSMs, is built upon action research principles and views organisations as complex adaptive knowledge-based systems; but unlike other SSMs PrOH modelling's novelty lies in the fact that it can be used to explore systemic issues by modelling holons (Koestler, 1967) and holarchies (Ulleru et al, 2002) in organisations to help form consensus about innovation, management of tacit knowledge (Muñoz et al., 2015) in respect to change (Clegg, 2007). A 'holon'. is a quasi-autonomous whole at one level and is also a part of a quasi-autonomous higher level whole, and contains parts which are also quasiautonomous wholes. A 'holarchy' is a set of holons arranged in a non-hierarchical formation (Clegg, 2007). Together the concepts of holons and holarchies are an essential property of any modelling methodology for modelling systems at more than one organisational 'pitch' (i.e. levels of organizational analyses such as strategic, tactical and operational) without overly relying on reductionist based approaches (Clegg, 2007). Reductionism is not appropriate for modelling human activity systems (HASs) (Checkland, 1981, p.52) such as legal services (Checkland and Scholes,

Ben Clegg, Krishna Balthu \& Glyn Morris (2019): Changing professional service archetypes in a law firm using Process Orientated Holonic (PrOH) Modelling, Knowledge Management Research \& Practice, DOI: 
1996) because hidden and emergent properties of systems and knowledge, their subsystems and meta-systems, and respective knowledge, can be lost.

$\mathrm{PrOH}$ Modelling is suitable to depict and investigate ineffable strategic systems, knowledge and processes - such as managing change projects - as these are infrequently performed, highly varied and provide few repeat experiential learning opportunities. $\mathrm{PrOH}$ modelling describes systemic causality within the change process without having to model the before ('as-is') and after ('to-be') states of processes; $\mathrm{PrOH}$ modelling encourages the sharing of explicit and tacit information and knowledge better than mechanistic, hierarchical 'before-and-after' (a.k.a 'as-is' and 'tobe') modelling approaches (as described by Bou et al., 2004) as PrOH modelling encourages richer language, wider interpretation and more phenomenology to be used. Which are all important methodological feature for knowledge-based changes in PSFs.

Therefore PrOH Modelling (Clegg, 2007) was used as a method to facilitate, plan and take action in each legal service. As a Soft Systems Methodology (SSM) it was used to build models of human activity systems (HASs). As the models are holonic; $\mathrm{PrOH}$ modelling was used to build holons of these five different services, which were then abstracted to form a single firm level holon of Higgs \& Sons. The set of holonic models together formed a holarchy (Jackson and Keys, 1984) rather than a hierarchy (Montilbeller et al, 2006). As a holarchy both "information" and "knowledge" (Früauff et al., 2015) are able to be captured at operational, tactical and strategic pitches of modelling, as holarchical modelling allows for hidden and emergent properties to be exhibited at any level of modelling. This is the first case where $\mathrm{PrOH}$ modelling has been used in a professional service firm.

The $\mathrm{PrOH}$ models represented tactical level views of each process delivering these five legal services and described the interactions between its people, systems, tangible and intangible knowledge. In this way the service delivery process of each legal service was depicted as a 'Human Activity System' (Checkland, 1981, p.52).

Ben Clegg, Krishna Balthu \& Glyn Morris (2019): Changing professional service archetypes in a law firm using Process Orientated Holonic (PrOH) Modelling, Knowledge Management Research \& Practice, DOI: 
Using these $\mathrm{PrOH}$ models the action research team was able to conceptualise,

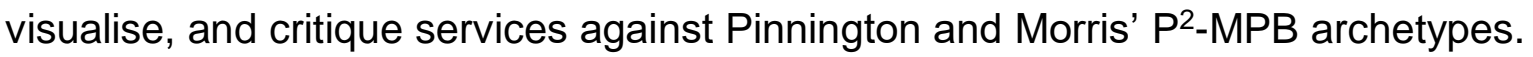

Another unique feature of $\mathrm{PrOH}$ modelling meant that the action research team was able to create a storyboard of each service which gave the modeller-facilitator the ability to solicit feedback on the process 'story' from a group of its stakeholders; this replicates other previously successful studies in manufacturing organisations using $\mathrm{PrOH}$ modelling (Clegg and Shaw, 2008). 'Storyboarding' is a term derived from the film industry to depict sequential scenes or episodes in a film; in a PrOH model it is used similarly to show knowldege-based scenes of a process in change one at a time (starting with the basic core process statement derived from the template in Figure 3) along with success factors (Rockart, 1979). Other scenes are then added in one at a time to build a picture relating to a systemic story and enrich the audiences tacit knowledge about it.

$\mathrm{PrOH}$ models were built and validated during a series of working sessions with stakeholders from each legal service. In total 30 one-to-one two hour interviews were used to construct the initial $\mathrm{PrOH}$ models during the action research process. Models were validated as 'defensible' representations of the real world, and were verified to make sure that they adhered to the rules and guidelines for constructing a $\mathrm{PrOH}$ model (Clegg, 2007). PrOH Models were iterated several times as necessary, as in good 'double loop learning' practice (Argyis \& Schon, 1978) to ensure their empirical usability (Fitzgerald, 1996, p. 12) and modelling verity. Thus $\mathrm{PrOH}$ modelling uses an interpretive paradigm with groups of stakeholders via social interaction (Montibeller et al., 2006).

A template of a $\mathrm{PrOH}$ model holon, on which all $\mathrm{PrOH}$ models are based, is given in Figure 3; it is similar in purpose to Checkland's SSM 'root definition' and 'conceptual model' (Checkland and Scholes, 1990) as it helps to define the essential parts of each model. However, there are three significant differences. Firstly, Checkland's SSM conceptual models are of an ideal system, whereas the $\mathrm{PrOH}$ model is of an actual change system under observations and its changing dynamics. Secondly, in SSM

Ben Clegg, Krishna Balthu \& Glyn Morris (2019): Changing professional service archetypes in a law firm using Process Orientated Holonic (PrOH) Modelling, Knowledge Management Research \& Practice, DOI: 
there are multiple root definitions and conceptual models, each associated with a different Weltanschauung (world-view) whereas PrOH models have only one model of each system representing a consensual view. Thirdly, SSM conceptual models are free format, while PrOH models use a template to help construct the model (Figure 3).

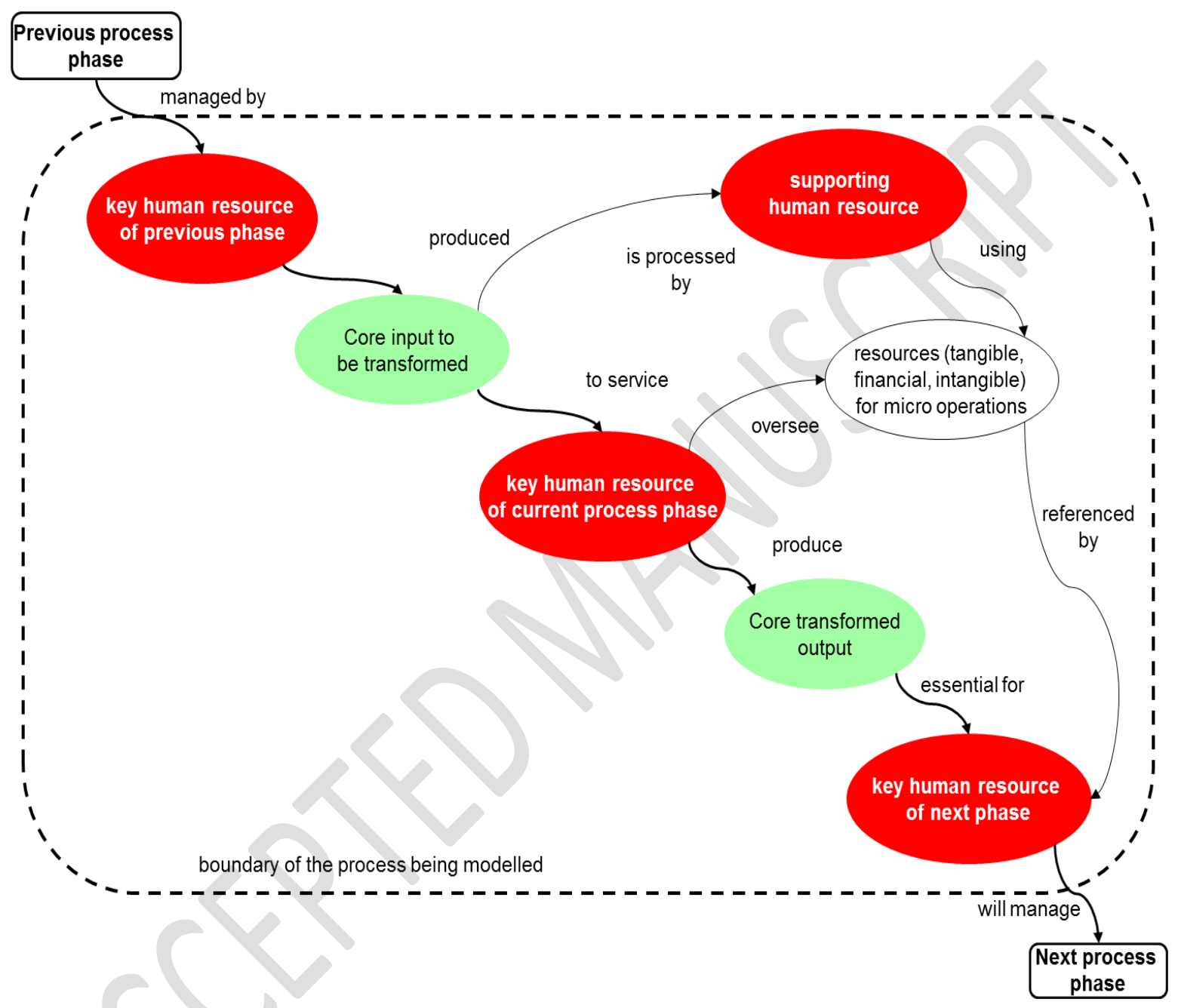

Figure 3: The PrOH holon template - "key human resource of current process phase produce core transformed output". Source: Clegg \& Shaw (2008)

The bold arrows in the PrOH model template (Figure 3) run from top left to bottom right and show the core process necessary for building a holon. The remaining paths in the template show descriptions of supporting activities which are added to and adapted to produce specific instantiations. Holons may be strategic, tactical or operational, and can be connected vertically upwards through abstraction techniques, or vertically

Ben Clegg, Krishna Balthu \& Glyn Morris (2019): Changing professional service archetypes in a law firm using Process Orientated Holonic (PrOH) Modelling, Knowledge Management Research \& Practice, DOI: 
downwards through enrichment techniques (whether processes are sequential or parallel); or can be connected laterally by sequential chaining. The detailed techniques for doing this are not covered in this paper, due to reasons of brevity; however the strategic high-level model, produced by abstraction, of Higgs \& Sons (from five tactical-level service $\mathrm{PrOH}$ models) is given later in Figure 4, and its elements are discussed using abductive logic against the $\mathrm{P}^{2}$-MPB service archetype model. It is significant to highlight that this is the first time a strategic-level $\mathrm{PrOH}$ model has been produced through parallel abstraction, rather than sequential abstraction, of tactical level PrOH models.

Once built each $\mathrm{PrOH}$ model was used as a discussion vehicle in a workshop with key stakeholders; $\mathrm{PrOH}$ models were presented in scene-by-scene storyboards. Each scene in the process allowed participants to debate better alternative approaches, as to whether a service should move towards or away from $\mathrm{P}^{2}$ towards MPB, and whether the volume-variety offering was innovative enough for future operational and knowledge based capabilities.

\subsubsection{CAR Stage 3 - Taking Action / Intervening (in five services)}

Action teams were formed by drawing people from each legal service and from central support departments (e.g. accounts, information technology, secretarial); they agreed tasks originating from the $\mathrm{PrOH}$ story-boarding workshops and took appropriate actions. A neutral (academic) PrOH modelling expert acted as a mentor and facilitator throughout the research process. A description of the systemic success factors (SSFs) - aspects that influence the behaviour of the system (a.k.a its holons and holarchy) are now given for each legal service. Each service formed its own action research cycle lasting approximately 12 months; cycles were staggered and overlapping running between months two to 23 . Changes to 'systems' as per Pinnington and Morris (2003) are described for each service.

\section{Service 1: Road Traffic Accident (RTA) Claims}

Processing a typical RTA requires interaction with fifteen external organisations (e.g. third parties' insurers, triage assessors, medical experts etc.), all of whom affect 
settlement timescales (up to fifteen months) which makes it difficult to estimate timescales and maintain service expectations for clients, plan work accurately and measure performance effectively. Lawyers have to liaise and obtain essential knowledge from all external stakeholders to reduce processing time whilst preserving the quality of service. Process efficiency is crucial and effective streamlining of operations helps to reduce costs. The systemic success factors (SSFs) for the lawyer and client are given in Table 3 and exhibit archetypical MPB behaviour.

\begin{tabular}{|c|c|c|c|}
\hline \multicolumn{2}{|c|}{ Systemic Success Factors } & Operational and & Changes \\
\hline For Lawyer & For Client & \multirow{3}{*}{$\begin{array}{l}\text { Improving client } \\
\text { experience - adhering to } \\
\text { standard procedures } \\
\text { whilst maintaining the } \\
\text { same level of personal } \\
\text { service. } \\
\text { Reducing turnaround } \\
\text { time (to } 3 \text { weeks) for } \\
\text { reaching settlement. } \\
\text { Streamlining internal } \\
\text { finance procedures. } \\
\text { Understanding client } \\
\text { needs and improving } \\
\text { service quality. }\end{array}$} & \multirow{3}{*}{$\begin{array}{l}\text { A new method to } \\
\text { engage with } \\
\text { clients - increased } \\
\text { conversion rate of } \\
\text { referrals from } \\
67 \% \text { to } 93 \% \text {. } \\
\text { Improved } \\
\text { documentation } \\
\text { quality and } \\
\text { standard. } \\
\text { Improved } \\
\text { relationship with } \\
\text { an institutional } \\
\text { client. }\end{array}$} \\
\hline $\begin{array}{l}\text { Complexity of the case - } \\
\text { number of parties } \\
\text { involved, claim amount, } \\
\text { personal injury. }\end{array}$ & $\begin{array}{l}\text { Recovery of damages } \\
\text { (justice, claim amount, } \\
\text { rehabilitation). }\end{array}$ & & \\
\hline $\begin{array}{l}\text { Turnaround time for } \\
\text { receiving documentation } \\
\text { from outside parties. }\end{array}$ & $\begin{array}{l}\text { Quicker settlement. } \\
\text { Personal service - } \\
\text { answer all queries, } \\
\text { provide assurance } \\
\text { and help recover } \\
\text { damages to the best } \\
\text { possible extent. }\end{array}$ & & \\
\hline
\end{tabular}

Table 3: Systemic success factors in the Road Traffic Accident claims Department.

\section{Service 2: Dispute Resolution Services}

Dispute Resolution (i.e. litigation) can be described as one of the more complex areas of law as it overlaps with many other legal disciplines. Although the volume of cases is relatively low, each case is unique and requires high levels of professional knowledge and customisation by lawyers to deal with the variety of cases. Professional work intensity is high as detailed legal arguments and strong links with clients develop, which makes managing the costs of litigation challenging, unpredictable and constantly prone to changes in factors such as: unexpected disclosures, counterclaims and submission of new expert evidence - many of which cannot be foreseen at 
the beginning of a case. Limited available knowledge at the outset often leads to case scope-creep, disproportionate costs, unnecessarily expended effort and general negative experiences for both lawyer (in unrecovered costs) and client (unintended outcome and costs). Thus emphasis becomes focused on building decision-making consensus, working on indivisible tasks and coping with widely distributed authority. Systemic success factors (SSFs) for the lawyer and client are summarised in Table 4, which are archetypical of $\mathrm{P}^{2} \mathrm{~S}$.

\begin{tabular}{|c|c|c|c|}
\hline \multicolumn{2}{|l|}{ Systemic Success Factors } & \multirow{2}{*}{$\begin{array}{l}\text { Operational and } \\
\text { Knowledge Challenges }\end{array}$} & \multirow{2}{*}{$\begin{array}{l}\text { Changes } \\
\text { Achieved }\end{array}$} \\
\hline For Lawyer & For Client & & \\
\hline $\begin{array}{l}\text { Complexity of case - number } \\
\text { of parties involved, area of } \\
\text { law, location of client, value of } \\
\text { claim, clear/vague } \\
\text { documentation, merits of the } \\
\text { case, witnesses required/not } \\
\text { required. } \\
\text { Client type - experience of } \\
\text { litigation, technical knowledge, } \\
\text { easy to advocate (expect } \\
\text { clients to follow the advice). } \\
\text { Managing client expectations } \\
\text { throughout (impacts on fee } \\
\text { recovery rate). }\end{array}$ & $\begin{array}{l}\text { Positive } \\
\text { outcome - } \\
\text { expected route } \\
\text { (settlement/go } \\
\text { to court), } \\
\text { expected value } \\
\text { of settlement. } \\
\text { Lawyer type - } \\
\text { expect lawyer to } \\
\text { be technically } \\
\text { sound, strategic } \\
\text { in dealing with } \\
\text { other side. } \\
\text { Cost of litigation } \\
\text { - proportionate } \\
\text { to the value of } \\
\text { claim, } \\
\text { transparent. }\end{array}$ & $\begin{array}{l}\text { Need for better pricing, } \\
\text { budgeting and scoping } \\
\text { mechanism. } \\
\text { Need for a robust process } \\
\text { for factoring in soft issues } \\
\text { such as managing client } \\
\text { expectations and driving } \\
\text { performance of fee } \\
\text { earners. } \\
\text { Understanding the } \\
\text { typology of litigation } \\
\text { cases to better estimate } \\
\text { prices. }\end{array}$ & $\begin{array}{l}\text { Delivered an } \\
\text { innovative } \\
\text { model (Case } \\
\text { Assessment } \\
\text { Radar) that will } \\
\text { act as a case } \\
\text { management } \\
\text { dashboard and } \\
\text { assists lawyers } \\
\text { in managing } \\
\text { the case and its } \\
\text { costs. } \\
\text { Developed a } \\
\text { budgeting tool } \\
\text { and standard } \\
\text { procedure for } \\
\text { driving } \\
\text { individual } \\
\text { performance. }\end{array}$ \\
\hline
\end{tabular}

Table 4: Systemic success factors within the Dispute Resolution Department.

\section{Service 3: Corporate Services}

Negotiating legal fees for corporate services, (e.g. large management buyouts) is notoriously challenging, as clients often supply the lawyers with insufficient knowledge at the outset. For example information on claims, disputes, opponent's lawyers and banks' lawyers may only come to light during the latter stages of the case and affect the time spent by the lawyers on a legal case. In addition there can often be excessive competitive pressure to win the work, and lawyers have to provide attractive quotes to 'out-do' the competition. In doing so lawyers often have to make assumptions at the 
outset of a case to arrive at a price quote, which may contain uncertain estimates and inaccurate initial projections of time and effort, which may ultimately result in loss of revenue in the form of a fee 'write-off'. The ability to produce near-accurate projections of billable hours is the 'holy grail' in negotiating, winning and sustaining legal business of this type. These systemic success factors were addressed by this project to increase this department's potential to win large merger and acquisition (M\&A) business, provide smaller business re-structures and become more affective at commercial contract transactions. Systemic success factors (SSFs) for lawyers and clients in Corporate Services are summarised in Table 5, which are archetypical of $\mathrm{P}^{2} \mathrm{~s}$.

\begin{tabular}{|c|c|c|c|}
\hline \multicolumn{2}{|c|}{ Systemic Success Factors } & \multirow{2}{*}{$\begin{array}{l}\text { Operational and } \\
\text { Knowledge } \\
\text { Challenges }\end{array}$} & \multirow{2}{*}{$\begin{array}{l}\text { Changes } \\
\text { Achieved }\end{array}$} \\
\hline For Lawyer & For Client & & \\
\hline $\begin{array}{l}\text { Case complexity - } \\
\text { Unknowns at the outset } \\
\text { (Due diligence facts, } \\
\text { disclosures, expectations } \\
\text { of clients), value of the } \\
\text { deal (e.g. management } \\
\text { buyout), number of } \\
\text { stakeholders, volume of } \\
\text { documentation, } \\
\text { amendments to } \\
\text { documents. } \\
\text { Fee recovery - time } \\
\text { spent by lawyer before } \\
\text { being instructed. } \\
\text { Timescales and } \\
\text { flexibility. } \\
\text { Knowledge of client and } \\
\text { the other side. }\end{array}$ & $\begin{array}{l}\text { Less involvement } \\
\text { in the process } \\
\text { and technicalities } \\
\text { - expect lawyers } \\
\text { to close the deal } \\
\text { smoothly. }\end{array}$ & $\begin{array}{l}\text { Quoting and } \\
\text { scoping the work. } \\
\text { Need for training in } \\
\text { negotiation skills. } \\
\text { Administrative } \\
\text { improvements in file } \\
\text { opening, archiving, } \\
\text { document } \\
\text { management. }\end{array}$ & $\begin{array}{l}\text { Designed a tool for } \\
\text { budgeting and } \\
\text { pricing. } \\
\text { Training needs } \\
\text { have been } \\
\text { identified and } \\
\text { agreed. } \\
\\
\text { Several protocols } \\
\text { have been } \\
\text { developed for } \\
\text { communication } \\
\text { between fee } \\
\text { earners and } \\
\text { secretarial support. } \\
\text { Document storing, } \\
\text { retrieving and } \\
\text { exchange have } \\
\text { been standardised. }\end{array}$ \\
\hline
\end{tabular}

Table 5: Systemic success factors, within the Corporate Services Department.

\section{Service 4: Commercial Property Services}

The Commercial Property Services Department provides bespoke services in a variety of property related legal matters. Drafting lease documentation is a process-driven activity. Lawyers act for both tenants and landlords, and even though the service can differ hugely depending which side the lawyer is acting on, clients of both sides are increasingly demanding fixed fee arrangements. This is because it is anticipated that 
fixed fee propositions will be the future of leasing transactions: which forces property lawyers to be more accurate on cost estimates whilst simultaneously preserving suitably high levels of personal client contact, which is a potentially conflicting set of performance characteristic and measures if not carefully managed. The success of this service lies in developing versatile capabilities able to cope with a high volume and high variety of case for large business clients, individual landlords, and private tenants. Systemic success factors for lawyers and clients are given in Table 6; which shows a desired move from a $\mathrm{P}^{2}$ delivery towards a MPB archetype. Such moves are more likely to be sustained through use of artificial intelligence (AI).

\begin{tabular}{|c|c|c|c|}
\hline \multicolumn{2}{|c|}{ Systemic Success Factors } & & s Achieved \\
\hline For Lawyer & For Client & iallenges & \\
\hline $\begin{array}{l}\text { Assumptions at the } \\
\text { outset - } \\
\text { Accepted/preferred } \\
\text { position of client. } \\
\text { Completion } \\
\text { timescale - move } \\
\text { in/move out dates. } \\
\text { Reporting } \\
\text { requirements. } \\
\text { Number of parties } \\
\text { involved in the } \\
\text { transaction. } \\
\text { Lawyers of other } \\
\text { side - amendments } \\
\text { to documents, } \\
\text { agreeing clauses. } \\
\text { Fee type - } \\
\text { fixed/hourly. }\end{array}$ & $\begin{array}{l}\text { Fixed fee. } \\
\text { Relationship } \\
\text { with lawyer } \\
\text { (institutional } \\
\text { clients). } \\
\text { Completion } \\
\text { timescale - } \\
\text { move in/move } \\
\text { out dates. }\end{array}$ & $\begin{array}{l}\text { Efficiency in process- } \\
\text { driven transactions. } \\
\text { Balancing personal } \\
\text { service while operating } \\
\text { on fixed fee. } \\
\text { Improving relationship } \\
\text { with institutional clients. } \\
\text { Effective work division } \\
\text { among senior and junior } \\
\text { fee earners. } \\
\text { Administrative routines } \\
\text { to be standardised. } \\
\text { Effective precedent and } \\
\text { document management. }\end{array}$ & $\begin{array}{l}\text { Designed a tool } \\
\text { based on historic } \\
\text { billing data for } \\
\text { effective work } \\
\text { allocation. } \\
\text { Developed protocols } \\
\text { for transferring } \\
\text { clients to other fee } \\
\text { earners. } \\
\text { Created precedent } \\
\text { bank and } \\
\text { repositories for } \\
\text { clauses. }\end{array}$ \\
\hline
\end{tabular}

Table 6: Systemic success factors within the Commercial Property Department.

\section{Service 5: Wills and Estate Services (Private Client)}

Drafting a legal will in most cases is a straight forward activity and can be standardised. This is one of the service areas most likely to be affected by competitive market forces as semi-qualified specialist will writers and 'supermarket law shops' pose an 
increasing threat to medium-sized law firms. The major challenges facing this department are: minimising cost of will production, building long-term relationships with clients, effective ability to cross-sell additional services and to provide additional value-adding services to clients. Systemic success factors for clients and lawyers are summarised in Table 7; which shows an essential move towards an MPB archetype from what traditionally has been a $\mathrm{P}^{2}$ archetype.

\begin{tabular}{|c|c|c|c|}
\hline \multicolumn{2}{|c|}{ Systemic Success Factors } & Operational and & Changes achieved \\
\hline For Lawyer & For Client & \multirow[b]{2}{*}{$\begin{array}{l}\text { Improving client } \\
\text { engagement whilst } \\
\text { maintaining compliance. } \\
\text { Improving time recovery. } \\
\text { Document reusability and } \\
\text { effective case } \\
\text { management. } \\
\text { Administrative routines to } \\
\text { be standardised. } \\
\text { Pricing and scoping } \\
\text { complex probate matters. }\end{array}$} & \multirow[b]{2}{*}{$\begin{array}{l}\text { Streamlined the } \\
\text { process of delivering } \\
\text { Standard Wills. } \\
\text { Streamlined the } \\
\text { process of raising } \\
\text { bills by introducing } \\
\text { automatic billing } \\
\text { functionality. } \\
\text { Designing a new } \\
\text { procedure for taking } \\
\text { enquiries and } \\
\text { allocating clients. }\end{array}$} \\
\hline $\begin{array}{l}\text { Case } \\
\text { complexity - } \\
\text { value of assets, } \\
\text { assets abroad, } \\
\text { number of } \\
\text { children etc. }\end{array}$ & $\begin{array}{l}\text { Flexibility, } \\
\text { Asset protection, } \\
\text { Tax mitigation. }\end{array}$ & & \\
\hline
\end{tabular}

Table 7: Systemic success factors, within the Wills \& Estate Department

\subsubsection{CAR Stage 4 - Analysing and Reflecting on Action}

A tactical level $\mathrm{PrOH}$ model was drawn for each service and a story-boarding session was conducted with key stakeholders from that department. Based on the abstraction principle laid out in the PrOH Modelling Methodology (Clegg and Shaw, 2008), a strategic view of Higgs \& Sons was produced from the five (parallel rather than sequential) quasi-autonomous service delivery processes, this strategic level model is shown in Figure 4 and is discussed in detail throughout Section 4.2 via abductive rationalisation in respect to the 'interpretive scheme' of Pinnington and Morris' $\mathrm{P}^{2}-$ MPB reference template (2003). A key to reading this $\mathrm{PrOH}$ model is given in Appendix 1.

Ben Clegg, Krishna Balthu \& Glyn Morris (2019): Changing professional service archetypes in a law firm using Process Orientated Holonic (PrOH) Modelling, Knowledge Management Research \& Practice, DOI: 


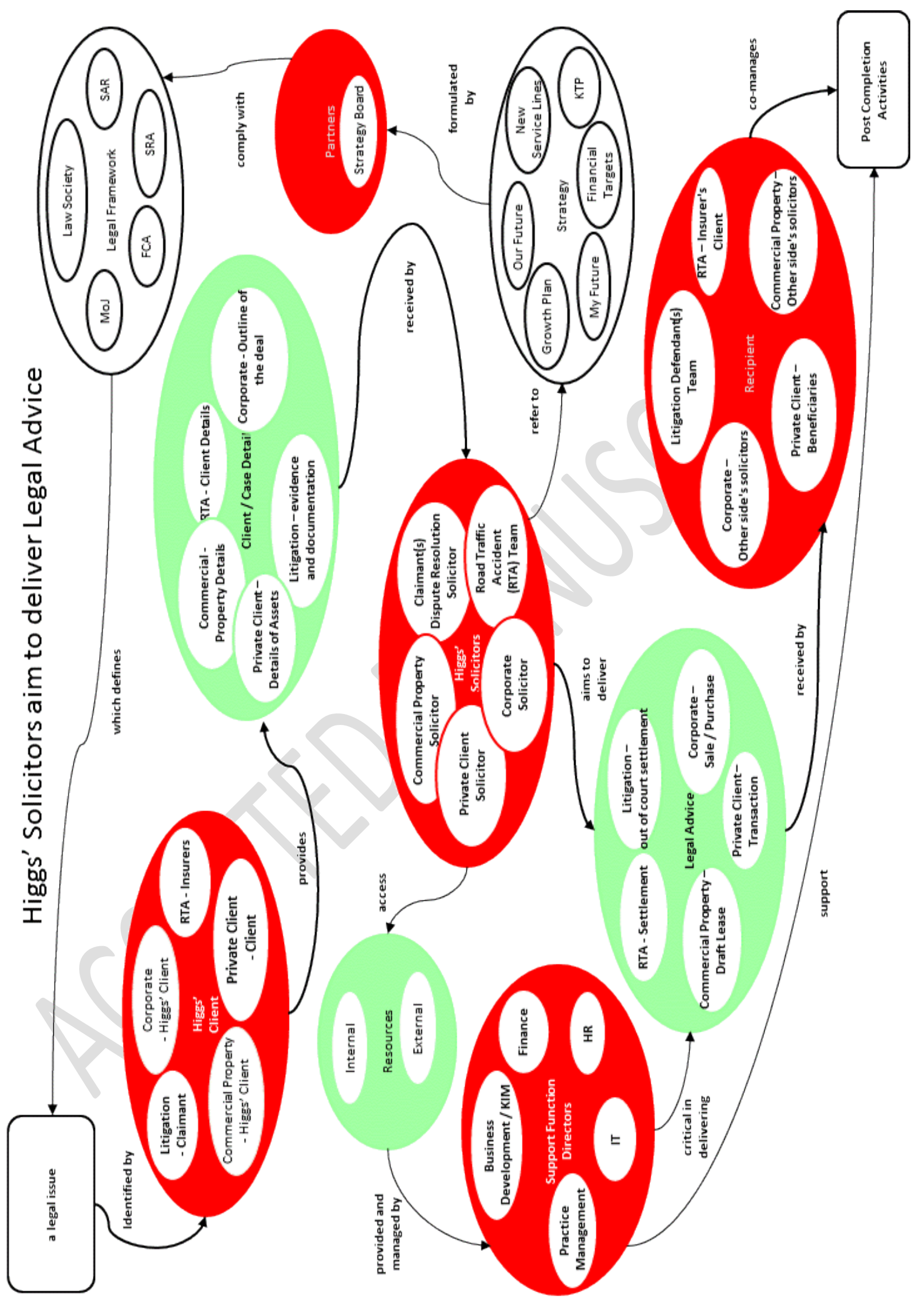

Figure 4: PrOH model: strategic level - Higgs \& Sons

Ben Clegg, Krishna Balthu \& Glyn Morris (2019): Changing professional service archetypes in a law firm using Process Orientated Holonic (PrOH) Modelling, Knowledge Management Research \& Practice, DOI: 10.1080/14778238.2019.1571387 


\subsubsection{CAR Stage 5: Engage with real world setting/situation}

The Canonical Action Research process produced five tactical PrOH models, (each with a storyboard).

A questionnaire survey poll (with responses from over half of the staff members 120/205) proved the increased propensities towards change by Higgs and Son's staff between the beginning (month 1) and the end of the project (month 24). In month 1 nearly all believed that widespread change was not necessary, but after changes,, in month $24,89 \%$ of participants believed that on-going changes were required to a 'moderate' extent and $71 \%$ believed that the change is 'extremely' urgent.

In the following section we discuss the emergent properties to the 'interpretive scheme' for Higgs \& Sons', as depicted by the PrOH model in Figure 4 (the 'strategic holon'). The discussion is an abstracted ('bottom-up') view produced from five tactical level $\mathrm{PrOH}$ models depicting the five parallel legal services (parallel 'tactical holons'). These models are available by contacting the authors.

\subsection{Reflection on frameworks}

This action research process has supported Higgs \& Sons' change from a predominantly $\mathrm{P}^{2}$ archetype towards an MPB archetype as defined by Pinnington and Morris' template (Table 1), sub-headings in this section refer to 'systems' and 'interpretive scheme' characteristics (as per Pinnington and Morris, 2003) .

\subsubsection{Systems - Lessons from Higgs \& Sons}

\subsubsection{Strategic Control}

Two partners (Heads of Departments for Private Client and Corporate Departments) were appointed to the principal decision-making body in Higgs \& Sons (the Strategy Board) due to their directive style of decision-making evident by the way in which they had previously managed their departments. However, these newly appointed members soon adjusted to take a more consultative and representative approach. As a result another external individual was very soon recruited and appointed as a non-

Ben Clegg, Krishna Balthu \& Glyn Morris (2019): Changing professional service archetypes in a law firm using Process Orientated Holonic (PrOH) Modelling, Knowledge Management Research \& Practice, DOI: 
executive director to provide additional directive support to the Strategy Board. The effect of this was that planning and action undertaken by the Strategy Board, and individual departments reporting to it, became more data-driven and the use of discursive focus groups became the norm; thus it became preferential to make decisions based on data and knowledge, rather than on 'expert opinion'; making the planning process more 'rational and analytical'. These changes are indicative of a strategic move away from a $\mathrm{P}^{2}$ archetype delivery towards more of a MPB archetype delivery.

\subsubsection{Marketing-Financial Control}

Marketing was an individual and person-centric concern for partners until the appointment of a new role - the Business Development Director as one of the Support Function Directors - that became responsible for co-ordinated all marketing related work across the firm, this activity had previously been managed by individual Departments and Partners. This move denotes a tendency towards 'centralisation' which is a tenet of an MPB archetype. Another new role came in the form of a Business Development Partner who worked closely with the Marketing and Business Development team. With a new and far more 'targeted' approach; the Corporate Department has now been able to succeed in servicing significantly larger corporate mergers and acquisitions involving international aspects. As a result the firm won some notable industry awards for innovation. Overall these marketing-financial changes have moved Higgs \& Sons more towards an MPB archetype.

\subsubsection{Operating Control}

There is a pronounced emphasis on 'planning' within Higgs \& Sons as Legal and Business Support departments are now required to draft three-year plans - something more characteristic of an MPB archetype rather than a $\mathrm{P}^{2}$ archetype. A newly formalised project management methodology for executing internal projects has also been developed and recently implemented through a newly created role for Project Manager for Organisational Change. This role has been created to provide project management support and implement changes to practice across the firm (including

Ben Clegg, Krishna Balthu \& Glyn Morris (2019): Changing professional service archetypes in a law firm using Process Orientated Holonic (PrOH) Modelling, Knowledge Management Research \& Practice, DOI: 
new IT systems). An Operations Board has been formed comprising of all Support Directors and two Partners to focus on the conception and delivery of internal projects supported by this new role. The Operations Board acts a sounding board for innovative ideas from both support and legal departments and makes decisions on which to pursue based on a cost-benefit analysis.

A bonus scheme, to emphasise and allocate reward and 'compensation' in the growing firm has also been introduced; at the time fo writing in its third year and constantly being improved in a response to feedback, this is a characteristic associated with an MBP archetype.

Higgs \& Sons have now obtained an Alternative Business Structure (ABS) status allowing non-lawyers to become partners in the firm. Following this change, a nonlawyer was appointed, for the first time, as a Partner. Again, this is another move taking Higgs \& Sons further towards an overall MPB archetype (as indicated by Pinnington and Morris, 2003).

\subsubsection{Interpretive Scheme - Lessons from Higgs \& Sons}

\subsubsection{Governance}

New entrants in the legal industry, who seek to exploit the Alternative Business Structure (ABS) opportunites, tend to approximate the MPB archetype rather than a traditional $\mathrm{P}^{2}$ archetype; they could emulate the changes made by Higgs \& Sons as documented in this paper. However widespread governance changes will take time to come to fruition as lawyers' behaviours are often 'sedimented' (Pinnington and Morris, (2003 p.95); this is especially prevalent in legal services that have low volumes and high variety and approximate $\mathrm{P}^{2}$ archetypes, and are managed and or owned by people who have relatively little knowledge of modern service operations practice. In Higgs \& Sons there is now a strategically planned blend of services with both $\mathrm{P}^{2}$ and MPB archetypes. Diehr and Wilhelm (2017) observed similar partial changes in other PSFs relative to the type of knowledge being shared and the strategic importance of

Ben Clegg, Krishna Balthu \& Glyn Morris (2019): Changing professional service archetypes in a law firm using Process Orientated Holonic (PrOH) Modelling, Knowledge Management Research \& Practice, DOI: 
a customer - with less knowledge intensive and less strategically important customers - being better suited to a MPB service style.

The research based on Higgs \& Sons does not suggest that MPB archetypes should completely replace or prevail over $\mathrm{P}^{2}$ archetypes, as some legal services, such as the legal dispute services, will probably never be entirely suited to MPB style operations; while other services such as RTA have already moved to MPB style operations. Neither should these archetype transitions be considered as discrete state changes, nor should they be applied across a whole company without considering the nuanced characteristics of each particular legal service. Instead $\mathrm{P}^{2}$-to-MPB service transitions should be considered as change continua on a service-by-service basis (or in some cases of larger or quickly growing companies on an office-by-office or local-office-andhead-quarters basis). Therefore a firm's high level governance must accommodate both types of archetypes ( $\mathrm{P}^{2}$ and MPB) and allow for dynamic transitions in response to a mix of tacit and explicit endogenous and exogenous forces, as discussed in the Higgs \& Sons case (Section 4.1.3), on a service-by-service basis.

\subsubsection{Effectiveness / Efficiency}

The divide between fee-earning staff (e.g. lawyers) and non-fee-earning staff (a.k.a. "fee burners") was seen as a barrier to systemic management improvement, as in other law firms (Forstenlechner et al., 2009) due to different personal characteristics, career structures and performance metrics; and so the use of cross-functional teams made a significant contribution to this research process by enabling cross-discipline knowledge sharing, development of trust, and melding of spatial organizational barriers (Love \& Roper, 2009). In this study the cross-functional action-research teams were composed of employees from different relevant legal services and different business support departments - who were empowered to work autonomously with support from their departmental heads. Teams solved long-standing organisational inefficiencies that were challenged and changed during this action research process (as described in Tables 3 to 7).

Ben Clegg, Krishna Balthu \& Glyn Morris (2019): Changing professional service archetypes in a law firm using Process Orientated Holonic (PrOH) Modelling, Knowledge Management Research \& Practice, DOI: 
$\mathrm{PrOH}$ model storyboarding helped to improve the overall understanding of complex legal processes by involving stakeholders from inside (e.g. partners and professional support staff) and outside (e.g. clients) the firm. By presenting systemic or "holistic" (Miller and Friesen, 1984) views of processes, both strategically and tactically pitched, improved knowledge sharing and stronger consensus on change was built across legal and business support departments. Narrating the process in simple and artful storyboarding, via $\mathrm{PrOH}$ modelling, enabled the research team to engage staff to reflect on current processes and identify potential improvements for delivering high value competitive services. One legal associate stated that, "... the big advantage was that this project brought people together who weren't necessarily working together ... some from IT, some from admin support, some lawyers ... and everyone brought their ideas". The effect of this was to help lawyer and professional support staff to work together more effectively and efficiently.

For instance, probably the biggest constraint to change in Higgs \& Sons and other law firms is time pressure, as lawyers predominantly operate on hourly billing. Therefore due to the opportunity costs, it is difficult to involve lawyers in organisation-wide change initiatives. This project overcame this hurdle by replacing many long formal meetings with brief 'standing meetings' where action teams shared ideas, proposed and agreed on solutions for improving specific areas (Weisbord and Janoff, 2005; Pot, 2011) based on the PrOH model storyboards. Tasks and timelines were agreed in these groups giving quick routes to solution implementation (see right-hand-side columns in Tables 3 to 7). Building on this success, a standardised practice has now been established for accessing ideas from staff which is now routinely applied to resolve problems. As stated by a Legal Associate, “... I just didn't have the time to properly devote myself to change initiatives. Every hour spent in internal meetings resulted in an extra hour added to the end of the day spent on chargeable work..."

\subsubsection{Primary Tasks}

Innovations at Higgs \& Sons included ideas about cost cutting, improving process flows, and enhancing peer-to-peer communication flows within teams (Kanter, 1983) that drew upon all employees' professional knowledge at all hierarchical organisational

Ben Clegg, Krishna Balthu \& Glyn Morris (2019): Changing professional service archetypes in a law firm using Process Orientated Holonic (PrOH) Modelling, Knowledge Management Research \& Practice, DOI: 
levels, rather than being concentrated in the hands of one or two high-level specialists (Shipton et al., 2006). So, although innovation is constantly required, lawyers are often limited by the so-called 'producer-manager' dilemma that can limit lawyers' potential to be innovative in respect to the firm's business and management related challenges (Lorsch and Mathias, 1987). Despite this, by working closely with lawyers, this action research project developed a raft of distributed innovative tools and practices that have been implemented by the action teams and has practically changed the way Higgs \& Son's lawyers perceive and think about business and management related issues (such as pricing, estimating when linking with clients and use of information technology) (see Tables 3 to 7). Making these improvements did not require large sums of capital investment but instead focused on the knowledge bases and creativity of staff to collectively and systemically generate new ideas and gain authentic buy-in to overcome existing inertia to change, partly by more widely distribute authority. For instance one of the partners stated that "I think this action research project probably made us realise things needed improving... as we found out that other departments had the same problems, and actually, if we put all our knowledge together we could begin to create a workable solution!"

\subsubsection{Marketing and Growth}

By using $\mathrm{PrOH}$ modelling and abductive rationalization against the $\mathrm{P}^{2}-\mathrm{MPB}$ template, in a CAR approach, practices relating to operations and knowledge in Higgs \& Sons have improved.

This project has enabled participants to research pluralistic systemic issues with conflicting stakeholder perceptions (Pidd, 1996), think creatively and artistically and reflect on known frameworks to improve the situation in which they found themselves (e.g. in situ roles). Co-production of ideas and deliverables throughout this action research was essential and achieved through the structured engagement process involving one-to-one interviews, storyboarding sessions and 'standing meetings' for the action teams. Reflection on Pinnington and Morris' (2003) P2 - MPB reference template also enabled 'double loop learning' opportunities, by rationalizing the underlying assumptions in a given problem situation and rethinking productivity 
metrics by which each should be judged; rather than pre-empting solutions without fully exploring all the options and neglecting to question current practices and frameworks (Argyris \& Schon, 1974). To illustrate, one partner expressed that "things such as open discussions, about what we can do better, getting individuals to think through problems, and to come up with recommendations for solutions by themselves is vitally important if we are going to innovative". As a result transitions from one service archetype to another have occurred, mostly from $\mathrm{P}^{2}$ towards MPB, and productivity metrics by which each is judged have been amended accordingly.

\section{Conclusion}

This research has contributed to practice by understanding challenges (c.f. aim i) and implementing changes (c.f. aim ii) in a medium-sized professional service law firm, using a unique form of SSM known as PrOH Modelling (Clegg, 2007). Perhaps most uniquely $\mathrm{PrOH}$ modelling has demonstrated that:

- it is not necessary to model 'before' and 'after' states of a strategic process, instead it can be better to model the systemic factors of the change process itself

- thinking systemically (using holons and holarchies via abstraction and enrichment) is not the same as thinking hierarchically (using hierarchies via aggregation and reduction). This difference is rarely registered or deployed.

- using systems thinking and holarchical based modelling can be innovative - by surfacing emergent (and hidden) knowledge within organizational and operational systems - in contrast to linear (or mechanistic) thinking and hierarchical based modelling which tends to define and optimize data-flows and processing logic.

- PrOH modelling - which is systemic and holonic - is ideally suited to catalyzing change projects that require group based innovative thinking to bring about changes in complex human activity systems in knowledge-based organizations without having to model before and after process states.

Ben Clegg, Krishna Balthu \& Glyn Morris (2019): Changing professional service archetypes in a law firm using Process Orientated Holonic (PrOH) Modelling, Knowledge Management Research \& Practice, DOI: 
For instance one lawyer exclaimed that, "I think we became a lot more aware of processes and knowledge driven service needs as a result of this approach and realised where we could improve. The effects of this project are going to be longlasting and significant!" (Senior Partner, Higgs \& Sons).

This research has also contributed to theory via abductive logic in respect to archetype changes from $\mathrm{P}^{2}$ towards MPB in a law firm in light of recent sector changes (c.f. aim iii). It also offers insight into how and why partial changes may occur through 'managerialism' of $P^{2}$ firms (Pinnington and Morris, 1993) (as per Section 4.1) and how subtle changes to the underlying interpretive scheme can affect service operations (as per Section 4.2.). Jonsson (2015) observed similar knowledge-based changes occurring in another law company case study as it moved from a predominantly 'knowledge management logic' practice to a 'professional logic' practice and on towards a predominantly 'business logic' practice.

The authors present this work as a case study on systemic change in response to recent changes in the UK legal sector and do not claim results to be entirely replicable or deterministic; however, they do claim it to be a successful and authentic action research project using SSM, abductive logic and the $\mathrm{P}^{2}-\mathrm{MPB}$ reference template.

\section{References}

Andreewsky, E. and Bourcier, D. (2000), Abduction in language interpretation and law making, Kybernetes, Vol.29 Nos.7/8, pp.836-45.

Argyris, C., and Schon, D. (1974). Theory in Practice: increasing professional effectiveness. San Francisco: Jossey Bass.

Bolisani, E., Scarso, E., and Giuman, L. (2016). Knowledge management in clientsupplier relationship: emergent vs deliberate approach in small KIBS. Knowledge Management Research and Practice. Vol.14, pp.178-185.

Bou, E. and Sauquet, A., (2004). Reflecting on quality practices through knowledge management theory: uncovering grey zones and new possibilities of process manuals, flowcharts and procedures. Knowledge Management Research and Practice. Vol.2 pp.35-47.

Checkland, P.B. (1981). Systems thinking, systems practice. Chichester: Wiley Checkland, P.B. and Scholes, J. (1990) Soft Systems Methodology in Action Chichester: Wiley.

Ben Clegg, Krishna Balthu \& Glyn Morris (2019): Changing professional service archetypes in a law firm using Process Orientated Holonic (PrOH) Modelling, Knowledge Management Research \& Practice, DOI: 
Clegg, B.T. (2007). Building a Holarchy using Business Process Orientated Holonic (PrOH) Modeling. IEEE Systems, Man and Cybernetics: Part A, Vol.31, No.1, pp.2340.

Clegg, B. and Shaw, D., (2008). Using process-oriented holonic (PrOH) modelling to increase understanding of information systems. Information Systems Journal, Vol.8, pp.447-477.

Cooper, D.J., Hinings, B., Greenwood, R., and Brown, J. (1996). Sedimentation and transformation in organizational change: The case of Canadian law firms. Organizational Studies, Vol.17, No.4. pp.623-647.

Diehr, G. and Wilhelm, S. (2017). Knowledge Marketing: how can strategic customers be utilised for knowledge marketing in knowledge-intensive SMEs? Knowledge Management Research and Practice. Vol.15, pp.12-22.

Dubois, A. and Gadde, L-E. (2002), Systematic combining: an abductive approach to case research, Journal of Business Research, Vol.55, pp.553-60.

Empson, L. (2007). Managing the modern law firm. Oxford: Oxford University Press.

Falconer, L. (2005). The Future of Legal Services: Putting Consumer First, Norwich: Department of Constitutional Affairs.

Fitzgerald, B. (1996) Formalised systems development methodologies: a critical perspective. Information Systems Journal, Vol.6, pp.3-23.

Forstenlechner. I, Lettice.F, and Tschida. M, (2009). Fee earner vs fee burner: internal divides in law firms. Employee Relations, Vol.31, No.1. pp.98-113

Freidson, E. (2001). Professionalism: The third logic. University of Chicago Press. Chicago.

Guardian, The (2012). www.guardian.co.uk. [Online] Available at: http://www.guardian.co.uk/law/2012/apr/02/abs-tesco-law-here. Accessed 6.12.2017. Galanter M. and T. Palay. (1991). Tournament of lawyers: The transformation of the large law firm. University of Chicago Press. Chicago.

Goodale, J. C., Kuratko, D. F. and Hornsby, J. S. (2008). Influence factors for operational control and compensation in professional service firms, Journal of Operations Management. Vol.26, No.5, pp.669-688.

Greenwood, R. and Hinings, C.R. (1993). Understanding strategic change: the contribution of archetypes. Academy of Management Journal. Vol.5, No.5, pp.10521081.

Greenwood, R., Hinings, C.R., and Brown, J. (1990). "P2-Form" strategic management: corporate practices in professional partnerships', Academy of Management Journal. Vol.33, No.4, pp.725-756.

Hayes, R.H. and S.C. Wheelwright. (1979a). Link manufacturing process and product life cycles. Harvard Business Review, Vol.57, No.1, pp.133-140.

Hayes, R.B., and Wheelwright, S.C. (1979b). 'The dynamics of process-product life cycles', Harvard Business Review, Vol.57, No.2, pp.127-136.

HMSO (2007). Legal Services Act 2007. HMSO. 11/2007.

Ben Clegg, Krishna Balthu \& Glyn Morris (2019): Changing professional service archetypes in a law firm using Process Orientated Holonic (PrOH) Modelling, Knowledge Management Research \& Practice, DOI: 
Hinings, C.R., Brown, J.L., and Greenwood, R., (1991) 'Change in an autonomous professional organisation', Journal of Management Studies. Vol.28, No.4. pp.375-393. Jackson, M.C., (2000). Systems Approaches to Management. New York: Plenum/Kluwer.

Jackson, M.C and Keys, P. (1984). Towards a system of system methodologies. Journal of the Operational Research Society. Vol.35, no.6, pp.473-486.

Jonsson, A., (2015). Beyond knowledge management - understanding how to share knowledge through logic and practice. Knowledge Management Research and Practice. Vol.13. pp.45-58.

Früauff, D.H., Kahrens, M., Menacere, K. and Mouzughi, Y., (2015) 'Rethinking knowledge hierarchies - bridging the gulf between theory and practice: the case of Frankfurt airport's billing department. Knowledge Management Research and Practice.Vol.13, pp.59-70.

Kaiser, S. and Ringlstetter, M. (2011). Strategic Management of Professional Services Firms: Theory and Practice. London: Springer.

Kanter, R. M., (1983). Change masters and the intricate architecture of corporate culture change, Management Review, Vol.72, No.10, pp.18-28.

Kirkeby, O.F. (1990), "Abduktion", in Andersen, H. (Ed.), Vetenskapsteori och metodlara. Introduktion, Studentlitteratur, Lund, Translated from Danish by Carl G. Liungman: 1994.

Lamma, E., Mello, P., Milano, M. and Riguzzi, F. (1999), Integrating induction and abduction in logic programming, Information Sciences, Vol.116, pp.25-54.

Lawrence, T.B., Malhotra, N. and Morris, T. (2012). Episodic and systemic power in the transformation of professional service firms. Journal of Management Studies. Vol.49, No.1, pp.102-143.

Lawson, T. (1998) Clarifying and developing the economics and reality project: closed and open systems, deductivism, prediction, and teaching. Review of Social Economy 51, pp.356-375.

Lewis, M. and Brown, A. (2012). How different is professional service operations management, Journal of Operations Management, Vol.30, No,1-2, pp.1-11.

Legal Services Act 2007. http://www.legislation.gov.uk/ukpga/2007/29/introduction. Accessed 19.10.2015

Lorsch J.W., and Mathias. P.F, (1987). When professionals have to manage. Harvard Business Review, Vol.65, No.4, pp.78-83.

Love, J. H. and Roper, S. (2009). Organizing innovation: complementarities between cross-functional teams, Technovation, Vol.29, No.3, pp.192-203.

Machuca, J., Gonzalez-Zamora, M.d.M., and Aguilar-Escobar, V.G. (2007). Service operations management research. Journal of Operations Management, Vol.25, No.3. pp.585-603.

Montilbeller, G., Shaw, D., Westcombe, M., (2006). Using decision support systems to facilitate the social process of knowledge management. Knowledge Management Research and Practice. Vol.4, pp.125-137.

Ben Clegg, Krishna Balthu \& Glyn Morris (2019): Changing professional service archetypes in a law firm using Process Orientated Holonic (PrOH) Modelling, Knowledge Management Research \& Practice, DOI: 10.1080/14778238.2019.1571387 
Miller, D., and Friesen, P. (1984). Organizations: a quantum view. Englewood Cliffs. NJ, USA. Prentice-Hall.

Morris, T. and Empson, L. (1998) Organisation and expertise: an explorations of knowledge bases and the management of accounting and consulting firms. Accounting, Organisations and Society. Vol.23, No.5/6. pp.609-624.

Muñoz, C.A., Mosey, S., Binks, M., (2015). The tacit mystery: reconciling different approaches to tacit knowledge. Knowledge Management Research and Practice. Vol.13, pp.289-298.

Nelson, R. (1988). Partners with Power: The Social Transformation of the Large Law Firm. Los Angeles: University of California Press.

Nordenflycht, A.V. (2010). What is a Professional Services Firm? Towards a Theory and Classification, Academy of Management Review, Vol.35, No.1, pp.155-174.

Pidd, M. (1996). Tools for Thinking: Modelling in Management Science. Chichester: Wiley.

Pilkington, A. and Chai, K-H. (2008), A study of International Journal of Service Industry Management (1990-2005). International Journal of Service Industry Management. Vol.19, No.1, pp.83-110.

Pinnington, A, and Morris, T. (2003), Archetype Change in Professional Organizations: Survey Evidence from Large Law Firms. British Journal of Management. Vol.14, No.1, pp.85-99.

Pot, F., (2011). Workplace innovation for better jobs and performance, International Journal of Productivity and Performance Management, Vol.60, No.4, pp.404-415.

Prajogo, D.I. and McDermott (2008). The relationships between operations strategies and operations activities in service context. International Journal of Service Industy Management. Vol.19. No.4. pp.506-520.

Ranson, S., Hinings, C.R., and Greenwood, R. (1980). 'An empirical taxonomy of work organizations. Administrative Science Quarterly. Vol.14, pp.115-126.

Schmenner, R. W. (1986). How Can Service Businesses Survive and Prosper?. Sloan Management Review. Vol.27, No.3, pp.21-32.

Segal-Horn, S. and Dean, A., (2007). The globalisation of law firms: managerial issues. International Journal of Service Industry Management. Vol.18, No.2, pp.206219.

Sherer, P, and Lee, K. (2002). Institutional change in large law firms: A resource dependency and institutional perspective, Academy of Management Journal. Vol.45, No.1, pp.102-119

Shipton, H., West, M., Dawson, J., Patterson, M. and Birdi, K. (2006). 'Human resource management as a predictor of innovation'. Human Resource Management Journal, Vol.16, No.1, pp.3- 27.

Silvestro, R., Fitzgerald, L., Johnston, R. and Voss, C. (1992). Towards a classification of service processes. International Journal of Service Industry Management, Vol.3, No.3, pp.62-75.

Ben Clegg, Krishna Balthu \& Glyn Morris (2019): Changing professional service archetypes in a law firm using Process Orientated Holonic (PrOH) Modelling, Knowledge Management Research \& Practice, DOI: 
Smets, M, Morris, T, and Greenwood, R. (2012). From practice to field: A multilevel model of practice-driven institutional change, Academy of Management Journal. Vol.55, no,4, pp.877-904.

SRA 2016, Solicitors Regulation Authority. Research and analysis: the changing legal services market. www.sra.org.uk/risk/resources/changing-legal-services-market.page . Accessed 14.11.2018.

Spens, K.M. and Kovács, G. (2006), A content analysis of research approaches in logistics research, International Journal of Physical Distribution \& Logistics Management, Vol.36, Iss.5, pp.374-390.

Susman, G.L. and Evered, R.D. (1978). An assessment of the scientific merits of action research, Administrative Science Quarterly, Vol.23, No.4, pp.582-603.

Van de Ven, A. (2007). Engaged Scholarship. Oxford University Press.

Svensson, G. (2006). New aspects of research into service encounters and service quality. International Journal of Service Industry Management. Vol17. No.3. pp.245257.

Ulleru, M., Brennan, R.W. and Walker, S.S. 2002. The Holonic Enterprise: A Model for Internet-Enabled Global Manufacturing Supply Chain and Workflow Management. Integrated Manufacturing Systems. Vol.13. No.8. pp.538-550.

Voss, C., (2009). Case research in operations management. In: C. Karlsson, ed. Researching operations management. New York, NY. Routledge. pp.162-195.

Voss, C., Johnson, M., and Godsell, J., (2016). Case Research in Karlsson. C., Ed. Research Methods for Operations Management. Routledge. New York. pp.179-184. Weisbord, M. and Janoff, S., (2005). Faster, shorter, cheaper may be simple: It's never easy, The Journal of Applied Behavioural Science, Vol.41, No.1, pp.70-82.

Ben Clegg, Krishna Balthu \& Glyn Morris (2019): Changing professional service archetypes in a law firm using Process Orientated Holonic (PrOH) Modelling, Knowledge Management Research \& Practice, DOI: 


\section{Appendix 1: A key to reading PrOH models}

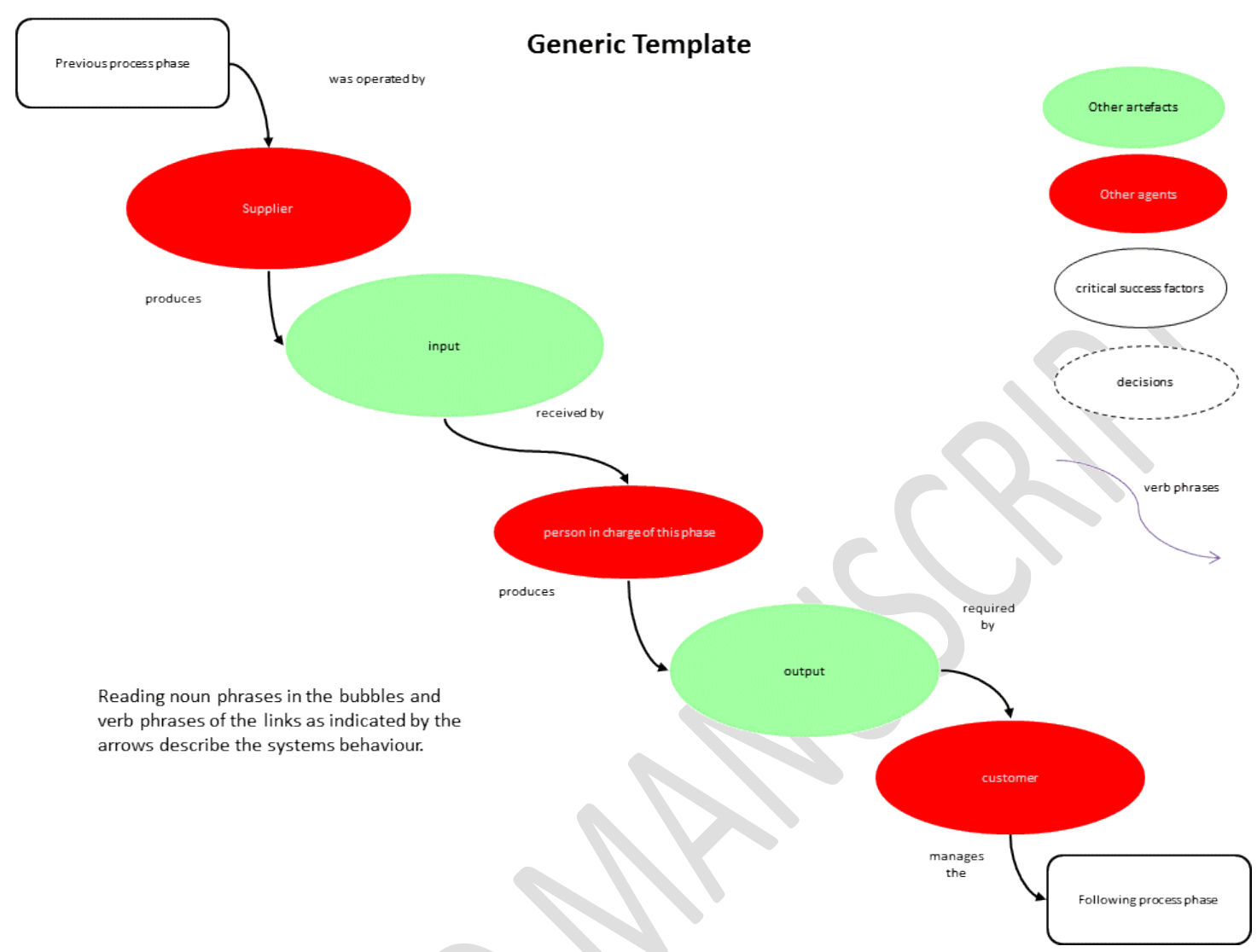

PrOH Modelling has scientific rules and artistic guidelines.

Ben Clegg, Krishna Balthu \& Glyn Morris (2019): Changing professional service archetypes in a law firm using Process Orientated Holonic (PrOH) Modelling, Knowledge Management Research \& Practice, DOI: 